\title{
In vitro bacteriostatic activity of Origanum vulgare, Cymbopogon citratus, and Lippia alba essential oils in cat food bacterial isolates
}

\section{Atividade bacteriostática in vitro dos óleos essenciais de Origanum vulgare, Cymbopogon citratus e Lippia alba em isolados bacterianos oriundos de rações de gatos}

\author{
Monique Catarine Fischer Possamai ${ }^{1}$; Isabela Carvalho dos Santos ${ }^{2 *}$; \\ Eloísa Schneider Silva ${ }^{3}$; Zilda Cristiani Gazim4; José Eduardo Gonçalves ${ }^{5}$; \\ Andréia Assunção Soares ${ }^{6}$; Ricardo de Melo Germano ${ }^{6}$; Maurício Fanin²; \\ Thaís Camaso de Sá7; Luciana Kazue Otutumi ${ }^{6}$
}

\begin{abstract}
The pet industry is currently expanding and specializing mainly in the field of domestic felines. Problems related to antimicrobial resistance are frequent, and the use of essential oils (EOs) in animal feed has become a novel treatment strategy. Thus, the objective of this study was to assess the bacteriostatic activity of Brazilian lemon balm (Lippia alba), lemon grass (Cymbopogon citratus), and oregano (Origanum vulgare) in bacterial isolates from 12 samples of cat food sold in bulk. The EOs from fresh leaves of crops were obtained from the Medicinal Garden of Paranaense University, Umuarama, Paraná. Cat food samples were processed for identification of gram-positive and gram-negative microorganisms. The determination of the bacteriostatic activity of the EOs was performed by determination of the minimum inhibitory concentration (MIC) at dilutions of $2.5,1.25$, and $0.62 \mathrm{mg} / \mathrm{mL}$. The diffusion disc technique was used to evaluate the resistance profile to the main antimicrobials used in the feline clinic and to analyze the effect of the association of these antimicrobials with the EOs studied. A total of 23 isolates were obtained, of which 16 were gram-negative and seven were gram-positive. As for the oil composition for L. alba, C. citratus, and O. vulgare, 40, 24, and 44 compounds were identified, respectively, with the major ones being geranial, geranial/ $\alpha$-citral, and carvacrol, respectively. Regarding MIC, no differences were found for any EOs tested. The lowest MIC value was obtained for the C. citratus $\mathrm{EO}(0.83 \mathrm{mg} / \mathrm{mL})$ for two bacteria (coagulase-negative Staphylococcus and Corynebacterium kutscheri). The means of the inhibition halos for the 10 antimicrobials tested in association or not with one of the EOs for Klebsiella aerogenes, Proteus vulgaris, and Serratia rubidaea showed that, for S. rubidaea, the inhibition halo diameter $(12.4 \mathrm{~mm})$ was greater $(p<0.05)$ when amoxicillin was associated with the $O$. vulgare EO than the association of the same antibiotic with the C. citratus EO $(11.0 \mathrm{~mm})$. For $K$. aerogenes and $P$.
\end{abstract}

M.e em Ciência Animal, Universidade Paranaense, UNIPAR, Umuarama, PR, Brasil. E-mail: mo.fischer@hotmail.com

2 Discentes de Doutorado em Ciência Animal com Ênfase em Produtos Bioativos, UNIPAR, Umuarama, PR, Brasil. E-mail: isabela_carvalhoxd@hotmail.com; fanin@hotmail.com

3 Discente de Mestrado em Biotecnologia Aplicada à Agricultura, UNIPAR, Umuarama, PR, Brasil. E-mail: eloisa.s@edu. unipar.br

4 Pesquisadora, Programa de Pós-Graduação em Biotecnologia Aplicada à Agricultura, UNIPAR, Umuarama, PR, Brasil. E-mail: cristianigazim@prof.unipar.br

5 Prof., Centro Universitário de Maringá, UNICESUMAR, Maringá, PR, Brasil. E-mail: jegoncal@gmail.com

6 Pesquisadores, Programa de Pós-Graduação em Ciência Animal com Ênfase em Produtos Bioativos, UNIPAR, Umuarama, PR, Brasil. E-mail: andreia.assuncao@prof.unipar.br; prof.ricardogermano@gmail.com; lkotutumi@gmail.com

7 Discente de Mestrado em Ciência Animal com Ênfase em Produtos Bioativos, UNIPAR, Umuarama, PR, Brasil. E-mail: thaiscamaso@outlook.com

Author for correspondence 
vulgaris, there was no difference in inhibition halo diameter when EOs were included. In conclusion, $L$. alba, C. citratus, and $O$. vulgare EOs are effective in inhibiting the growth of gram-positive and gramnegative bacteria and can be added to cat food to replace chemical antimicrobials.

Key words: Minimum inhibitory concentration. Carvacrol. Geranial. Resistance.

\section{Resumo}

Atualmente, a indústria pet vem se expandido e se especializando principalmente na área de felinos domésticos. Além disso, problemas relacionados à resistência aos antimicrobianos são frequentes e o uso de óleos essenciais (OEs) nas rações destinadas à alimentação animal têm se tornado uma nova estratégia de tratamento. Dessa forma, o objetivo do trabalho foi avaliar a atividade bacteriostática dos OEs de erva-cidreira brasileira (Lippia alba), capim-limão (Cymbopogon citratus) e orégano (Origanum vulgare) em isolados bacterianos oriundos de 12 amostras de rações de gato comercializados a granel. Os OEs foram obtidos das folhas frescas de culturas oriundas do Horto Medicinal da Universidade Paranaense, Umuarama, Paraná. As amostras de ração foram processadas para identificação dos microorganismos Gram-positivos e Gram-negativos. A determinação da atividade bacteriostática dos OEs foi feita por meio da determinação da concentração inibitória mínima (CIM) para as diluições de 2,5; 1,25 e $0,62 \mathrm{mg} / \mathrm{mL}$. A técnica de disco difusão foi utilizada para avaliar o perfil de resistência aos principais antimicrobianos utilizados na clínica de felinos e para a análise do efeito da associação destes com os OEs estudados. Foram obtidos 23 isolados, dos quais 16 eram gram-negativos e sete grampositivos. Em relação à composição dos OEs, foram identificados para os óleos de L. alba, C. citratus e $O$. vulgare, 40, 24 e 44 compostos respectivamente, cujos compostos majoritários foram geranial, geranial $/ \alpha$-citral e carvacrol, respectivamente. Em relação à CIM, não foram verificadas diferenças para nenhum dos OEs testados. O menor valor da CIM foi obtido para OE de C. citratus $(0,83 \mathrm{mg} / \mathrm{mL})$ para duas bactérias (Staphylococcus coagulase negativa e Corynebacterium kutscheri). A média dos halos de inibição aos 10 antimicrobianos testados em associação ou não a um dos OEs para $K$. aerogenes, $P$. vulgaris e $S$. rubidaea demonstrou que para a $S$. rubidaea, houve maior $(\mathrm{P}<0,05)$ diâmetro do halo de inibição $(12,4 \mathrm{~mm})$ quando da associação da amoxicilina com $\mathrm{OE}$ de $O$. vulgare em comparação com associação do mesmo antibiótico com o $\mathrm{OE}$ de $C$. citratus $(11,0 \mathrm{~mm})$. Para $K$. aerogenes e $P$. vulgaris não foram verificadas diferenças no diâmetro do halo de inibição quando da inclusão dos OEs. Concluise que os OEs de $L$. alba, C. citratus e $O$. vulgare são eficazes na inibição do crescimento de bactérias gram-positivas e gram-negativas, podendo vir a ser introduzidos na ração de felinos em substituição aos antimicrobianos químicos.

Palavras-chave: Concentração inibitória mínima. Carvacrol. Geranial. Resistência.

\section{Introduction}

The Brazilian pet industry is at the third place in the world market, following the United States and the United Kingdom (ASSOCIAÇÃO BRASILEIRA DA INDÚSTRIA PARA ANIMAIS DE ESTIMAÇÃO - ABINPET, 2017). ABINPET (2015) estimates that the cat population will multiply and surpass that of other pets in less than 10 years, indicating a need for more studies in the field of cat-related nutrition and feeding. Many cat owners usually purchase their pet ration in bulk, increasing the risk of feed contamination due to increased handling and exposure of the ration to environmental contamination.

In addition, the increased dissemination of antimicrobial-resistant microorganisms has encouraged the search for new antimicrobial molecules, including those derived from plants because of their antimicrobial action, low cost, and ease of production (BAPTISTA, 2017). Extracts of plants or their metabolic components, as well as essential oils (EOs) are among the most researched products. 
According to Koketsu and Gonçalves (1991), EOs are volatile compounds characterized by a mixture of substances of varied chemical functions present in several parts of plants such as flowers, leaves, fruits, seeds, and roots and are mostly extracted by steam distillation.

Several EOs have been assessed for their antimicrobial potential such as EOs from oregano Origanum vulgare (SANTURIO et al., 2007; SILVA et al., 2010; SANTOS et al., 2011; NASCIMENTO et al., 2014; ARAÚJO; LONGO, 2016), lemon grass Cymbopogon citratus (OLIVEIRA et al., 2011; ASSIS et al., 2017), and lemon balm Lippia alba (AQUINO et al., 2010). However, investigations that analyze their use in isolates from samples of cat food sold in bulk are still scarce.

Thus, the objective of this study was to assess the bacteriostatic activity of $O$. vulgare, $C$. citratus, and $L$. alba EOs in bacterial isolates from samples of cat food (low-cost, standard, and premium) sold in bulk.

\section{Material and Methods}

\section{Plant material}

The plant material to obtain the EOs was collected from $O$. vulgare, $C$. citratus, and L. alba crops from the Medicinal Garden of Paranaense University, UNIPAR in the municipality of Umuarama PR, S23 ${ }^{\circ} 46.225^{\prime}$ and $\mathrm{W} 53^{\circ} 16.730^{\prime}$, altitude of $391 \mathrm{~m}$. Fresh leaves were harvested manually in the early morning, between 6:30 and 8:00 for subsequent EO extraction. The choice of these hours is based on the volatility of the EOs at temperatures above $35^{\circ} \mathrm{C}$, because EOs are not very stable in the presence of light and high temperatures (ROCHA et al., 2012). A specimen voucher of $O$. vulgare L. (HEUP 31), C. citratus (DC.) Stapf (HEUP 28), and L. alba (Mill.) N.E. Br. (HEUP 15) was deposited in the Educational Herbarium of the Paranaense University. The plant species used in the present study are registered in the National System of Management of Genetic Heritage and Associated Traditional Knowledge (SisGen) under the number AC89D16.

\section{Extraction of EOs}

EOs were obtained by hydrodistillation using a modified Clevenger device (GAZIM et al., 2010, 2011). The plant-water ratio was $1: 10$ (250 g of fragmented fresh leaves to $2,500 \mathrm{~mL}$ of distilled water). Distillation lasted $2 \mathrm{~h}$, and the oil was removed with a Pasteur pipet, dried with anhydrous sodium sulfate $\left(\mathrm{Na}_{2} \mathrm{SO}_{4}\right)$ (SIMÕES; SPITZER, 2002), packed in amber flasks, and kept at $4^{\circ} \mathrm{C}$ (OMOLO et al., 2004).

\section{Chemical composition of the EOs}

The chemical composition of the O. vulgare, C. citratus, and L. alba EOs was analyzed by gas chromatography coupled to mass spectrometry GC/ MS using a gas chromatograph (Agilent 7890 B) coupled to a mass spectrometer (Agilent 5977A MSD) equipped with an HP-5 MS UI Agilent capillary column $(30 \mathrm{~m} \times 0.250 \mathrm{~mm} \times 0.25 \mu \mathrm{m})$. For the $O$. vulgare $\mathrm{EO}$, the initial column temperature was $60^{\circ} \mathrm{C}$ for $5 \mathrm{~min}$, which was raised by $3^{\circ} \mathrm{C} / \mathrm{min}$ up to $280^{\circ} \mathrm{C}$ and then by $20^{\circ} \mathrm{C} / \mathrm{min}$ up to $300^{\circ} \mathrm{C}$ (SARTORATTO et al., 2004). For the L. alba EO, the initial column temperature was $60^{\circ} \mathrm{C}$, which was increased by $3^{\circ} \mathrm{C} / \mathrm{min}$ up to $240^{\circ} \mathrm{C}$ and, finally, by $40^{\circ} \mathrm{C} / \mathrm{min}$ up to $300^{\circ} \mathrm{C}$ for 1 min (GOMES et al., 2012). For the C. citratus EO, the initial column temperature was $60^{\circ} \mathrm{C}$, being raised by $3^{\circ} \mathrm{C} / \mathrm{min}$ up to $246^{\circ} \mathrm{C}$, by $10^{\circ} \mathrm{C} / \mathrm{min}$ up to $270^{\circ} \mathrm{C}$ for $5 \mathrm{~min}$, and finally, by $10^{\circ} \mathrm{C} / \mathrm{min}$ up to $290^{\circ} \mathrm{C}$ for $10 \mathrm{~min}$ (SUBRAMANIAN et al., 2015) with modifications. The temperature of the injector was $220^{\circ} \mathrm{C}$ for $O$. vulgare and C. citratus and $250^{\circ} \mathrm{C}$ for $L$. alba. The carrier gas used was helium with a linear velocity of $1 \mathrm{~mL} / \mathrm{min}$ up to $300^{\circ} \mathrm{C}$ and with a pressure flow of $56 \mathrm{kPa}$; the injection volume was $2 \mu \mathrm{L}$, and injection procedures were carried out in split mode 
(20:1). The transfer line was maintained at $240^{\circ} \mathrm{C}$, and the ionization source and quadrupole at $230^{\circ} \mathrm{C}$ and $150^{\circ} \mathrm{C}$, respectively. The detection system was the Electron Multiplier in scan-mode, in the mass/ charge ratio $(\mathrm{m} / \mathrm{z})$ range of $40-550$, with a solvent delay time of $3 \mathrm{~min}$. Oil samples were diluted at a 1:10 proportion with dichloromethane.

The compounds present in the EOs were identified by comparing their mass spectra with the mass spectra found in the NIST 11.0 library and based on the comparison of their retention indices obtained using a homologous series of the n-alkane standard (C7-C30) (ADAMS, 2012).

\section{Collection of food samples}

Twelve samples of cat food sold in bulk from three categories available in the market (lowcost, standard, and premium) were collected. Four samples were collected from each category. After collection, the samples were sent to the Laboratory of Preventive Veterinary Medicine and Public Health of the Graduate Program in Animal Science of Paranaense University, UNIPAR for processing.

\section{Food samples processing}

A total of $25 \mathrm{~g}$ of each food sample was weighed and homogenized in $225 \mathrm{~mL}$ of $0.1 \%$ peptone water $\left(10^{-1}\right.$ dilution) according to the normalization ISO6887-4 (2003). The second dilution $\left(10^{-2}\right)$ was performed by transferring $1 \mathrm{~mL}$ of the $10^{-1}$ dilution into a test tube containing $9 \mathrm{~mL}$ of $0.1 \%$ peptone water, and the third dilution $\left(10^{-3}\right)$ was obtained following the same procedure. Afterwards, the samples were incubated in an oven at a temperature of $35^{\circ}$ to $36^{\circ} \mathrm{C}$ for $24 \mathrm{~h}$. Subsequently, the samples were plated on Petri dishes containing blood agar and MacConkey agar in duplicate for isolation and identification of contaminating microorganisms (gram-positive and gram-negative). From each dilution $\left(10^{-1}\right.$ and $\left.10^{-3}\right), 100 \mu \mathrm{L}$ of the sample was taken by inoculation on the surface of the solidified medium with the aid of a Drigalski loop. The dishes were incubated at temperatures of $35^{\circ} \mathrm{C}$ to $36^{\circ} \mathrm{C}$ for $24 \mathrm{~h}$. The isolated colonies were subjected to macroscopic observation for colony characteristics and microscopic observation for morphological and staining characteristics, as well as to subsequent biochemical tests, according to methodology described by Quinn et al. (1994). After identification, the isolates were frozen in BHI plus glycerol for further analysis.

Determination of minimum inhibitory concentration (MIC)

The MIC of the $O$. vulgare, C. citratus and $L$. alba EOs was determined using microtiter plates (96 wells) with a total volume of $100 \mu \mathrm{L}$, according to the methodology described by Gazim et al. (2010).

From the pilot test, the utilized microorganisms wereEscherichiacoli(ATCC25922), Staphylococcus aureus (ATCC 25923), Pseudomonas aeruginosa (ATCC 27853), and Streptococcus pyogenes (ATCC 19615). The EOs were diluted in a $2.0 \%$ aqueous polysorbate solution (80) at concentrations of 40 , $20,10,5,2.5,1.25$, and $0.62 \mathrm{mg} / \mathrm{mL}$. Dilutions of $2.5,1.25$, and $0.62 \mathrm{mg} / \mathrm{mL}$ were chosen to determine the MIC in the isolates $(n=23)$ from the cat food samples.

Each isolated sample was standardized according to $0.5 \mathrm{McF}$ arland scale, corresponding to a concentration of approximately $10^{8}$ colonyforming units (CFUs).

Each well contained BHI medium, dilutions of the O. vulgare, C. citratus, and L. alba EOs, and $5 \mu \mathrm{L}$ of the inoculum. The assays were performed in triplicate. MIC was determined after $24 \mathrm{~h}$ of incubation at $37^{\circ} \mathrm{C}$.

The smallest EO concentration without visible microbial growth in the optical microscope was defined as MIC. 


\section{Disc diffusion assay}

The bacteriostatic activity of the EOs was evaluated using the disc diffusion assay, according to the Clinical and Laboratory Standards Institute (CLSI, 2013), adapted for natural products. From a bacterial growth of 18 to $24 \mathrm{~h}$, three to five CFUs were inoculated in $5 \mathrm{~mL}$ of $0.85 \%$ saline solution. The suspension turbidity was adjusted by visual comparison to the standard 0.5 suspension of the McFarland scale. Subsequently, the suspension was seeded into a Müller-Hinton agar plate in three directions until a uniform smear was obtained and left at room temperature $\left(20-25^{\circ} \mathrm{C}\right)$ for $15 \mathrm{~min}$ for drying. Sterilized 6-mm filter paper discs were saturated with $5 \mu \mathrm{L}$ of each diluted $\mathrm{EO}(2.5 \mathrm{mg} / \mathrm{mL})$ and applied on agar. Readings were performed after $18-24 \mathrm{~h}$ of incubation at $35-37^{\circ} \mathrm{C}$, by measuring the inhibition halos of bacterial growth in millimeters of diameter.

Determination of antimicrobial resistance profile and verification of antagonistic or synergistic activity with $O$. vulgare, C. citratus, L. alba EOs

The antibiotic-resistance profile of Klebsiella aerogenes, Proteus vulgaris, and Serratia rubidaea, the most common isolated microorganisms, was investigated by disc diffusion test, according to the CLSI (2013). The discs of ampicillin $(10 \mu \mathrm{g})$, cephalothin $(30 \mu \mathrm{g})$, gentamicin $(10 \mu \mathrm{g})$, tetracycline $(30 \mu \mathrm{g})$, ciprofloxacin $(5 \mu \mathrm{g})$, tobramycin $(10 \mu \mathrm{g})$, amoxicillin $(10 \mu \mathrm{g})$, amoxicillin + clavulanate, penicillin $(10 \mu \mathrm{g})$, and ceftiofur $(30 \mu \mathrm{g})$ were selected for inclusion in the study based on their use in clinical routine for domestic cats. In addition, these antimicrobials were tested with some of the EOs for synergistic or antagonistic activity. The synergistic and antagonistic activity was evaluated using antimicrobial discs saturated with the dilution of $2.5 \mathrm{mg} / \mathrm{mL}$ of the evaluated oils.

\section{Statistical analysis}

The MIC from the dilutions of the oils (2.5, 1.25 , and $0.62 \mathrm{mg} / \mathrm{mL}$ ) was determined for the microorganisms isolated from the cat food. Afterward, differences between the oils were compared using the Kruskal-Wallis test at a $5 \%$ level of significance. The diameters of the inhibition halos of the 10 antibiotics tested on $K$. aerogenes, $S$. rubidaea, and $P$. vulgaris in association with some of the assessed oils were compared using analysis of variance or Kruskal-Wallis test. Bioestat 5.0 (AYRES et al., 2007) was used for these analyses.

A multivariate exploratory analysis was performed, determining the principal component analysis (PCA), allowing a joint assessment of the chemical classes of all the compounds present in $L$. alba, C. citratus, and O. vulgare EOs. The results of the analysis were presented in graphical form (Biplot), assisting in the characterization of the groups of the analyzed variables (MOITA NETO; MOITA, 1998). For each EO sample, the respective chemical classes as well as the area quantity in (\%) (Table 1) were plotted in Excel spreadsheets. These data were transformed into orthogonal latent variables called principal components, which were linear combinations of the original variables created with the eigenvalues of the data covariance matrix (HAIR et al., 2005). The Kaiser criterion was used to choose the principal components. An eigenvalue preserves relevant information when it is greater than the unit. Data were analyzed by grouping the chemical classes of the three analyzed oils to which these compounds belong. Both analyses were performed on Statistica 7 (STATSOFT, 2018). 
Table 1. Chemical composition of Lippia alba essential oil.

\begin{tabular}{|c|c|c|c|c|}
\hline Peak & ${ }^{\mathrm{A}}$ Compounds & ${ }^{\mathrm{a} R \mathrm{R}_{\mathrm{cal}}}$ & Área \% & $\mathrm{IM}$ \\
\hline 1 & Cis -3-hexenol & 802 & 0.31 & $a, b, c$ \\
\hline 2 & 1-octen-3-ol & 992 & 0.48 & $a, b, c$ \\
\hline 3 & 6-methyl-5-hepten-2-one & 1000 & 1.26 & $a, b, c$ \\
\hline 4 & Myrcene & 1005 & 3.39 & $a, b, c$ \\
\hline 5 & Trans- $\beta$-ocimene & 1068 & 0.53 & $a, b, c$ \\
\hline 6 & Myrtenol & 1118 & 0.07 & $a, b, c$ \\
\hline 7 & Linalool & 1127 & 1.14 & $a, b, c$ \\
\hline 8 & Trans-p-mentha-2,8-dien-1-ol & 1172 & 0.28 & $a, b, c$ \\
\hline 9 & Cis-epoxy-ocimene & 1179 & 0.23 & $\mathrm{a}, \mathrm{c}$ \\
\hline 10 & Trans-verbenol & 1184 & 0.53 & $a, b, c$ \\
\hline 11 & Citronellal & 1188 & 0.39 & $a, b, c$ \\
\hline 12 & n.i & 1201 & 0.99 & $a, b$ \\
\hline 13 & n.i & 1216 & 0.07 & $a, b$ \\
\hline 14 & Trans- carveol & 1226 & 1.48 & $a, b, c$ \\
\hline 15 & Cis-carveol & 1242 & 0.22 & $a, b, c$ \\
\hline 16 & Nerol & 1288 & 0.89 & $a, b, c$ \\
\hline 17 & Neral & 1306 & 27.80 & $a, b, c$ \\
\hline 18 & Geraniol & 1324 & 1.63 & $\mathrm{a}, \mathrm{b}, \mathrm{c}$ \\
\hline 19 & Geranial & 1250 & 35.07 & $a, b, c$ \\
\hline 20 & Trans -geraniol & 1329 & 0.14 & $a, b, c$ \\
\hline 21 & Eugenol & 1356 & 0.18 & $a, b, c$ \\
\hline 22 & $\alpha$-copaene & 1378 & 0.66 & $\mathrm{a}, \mathrm{b}, \mathrm{c}$ \\
\hline 23 & $\beta$-cubebene & 1391 & 0.18 & $\mathrm{a}, \mathrm{b}, \mathrm{c}$ \\
\hline 24 & $\beta$-elemene & 1400 & 1.75 & $a, b, c$ \\
\hline 25 & Methyl eugenol & 1421 & 0.10 & $\mathrm{a}, \mathrm{b}, \mathrm{c}$ \\
\hline 26 & Trans-caryophyllene & 1440 & 6.72 & $a, b, c$ \\
\hline 27 & n.i & 1452 & 0.12 & $\mathrm{a}, \mathrm{c}$ \\
\hline 28 & $\alpha$-humulene & 1485 & 0.44 & $a, b, c$ \\
\hline 29 & Trans- $\beta$ - farnezene & 1493 & 0.76 & $\mathrm{a}, \mathrm{b}, \mathrm{c}$ \\
\hline 30 & $\alpha$-amorphene & 1519 & 0.29 & $a, b, c$ \\
\hline 31 & Germacrene D & 1525 & 0.79 & $\mathrm{a}, \mathrm{b}, \mathrm{c}$ \\
\hline 32 & Valencene & 1554 & 0.34 & $\mathrm{a}, \mathrm{b}, \mathrm{c}$ \\
\hline 33 & $\alpha$-muurolene & 1560 & 0.15 & $\mathrm{a}, \mathrm{b}, \mathrm{c}$ \\
\hline 34 & $\gamma$-cadinene & 1575 & 0.07 & $\mathrm{a}, \mathrm{b}, \mathrm{c}$ \\
\hline 35 & n.i & 1582 & 0.84 & $\mathrm{a}, \mathrm{c}$ \\
\hline 36 & $\delta$-cadinene & 1586 & 0.12 & $a, b, c$ \\
\hline 37 & Cis-nerolidol & 1604 & 0.69 & $\mathrm{a}, \mathrm{b}, \mathrm{c}$ \\
\hline 38 & Trans-nerolidol & 1658 & 0.16 & $a, b, c$ \\
\hline 39 & Cariophyllene oxide & 1673 & 5.18 & $a, b, c$ \\
\hline 40 & Cis- $\alpha$-santalol & 1709 & 0.26 & $a, b, c$ \\
\hline
\end{tabular}


continuation

\begin{tabular}{llccc}
41 & n.i & 1740 & 0.07 & a,c \\
42 & Trans-2, trans-6-farnesol & 1771 & 0.28 & a,b,c \\
43 & 8-oxoneoisolongifolene & 1789 & 1.21 & a,c \\
44 & 15-copaenol & 1806 & 1.29 & a,c \\
45 & Trans- $\alpha$ sesqui ciclogeraniol & 1886 & 0.29 & a,c \\
46 & n.i & 1926 & 0.16 & a,c \\
\hline \multicolumn{1}{c}{ Total identified } & & 94.00 & \\
\hline & monoterpenes hydrocarbons & 3.92 & \\
& oxygenated monoterpenes & 71.11 & \\
& sesquiterpene hydrocarbons & 13.23 & \\
& oxygenated sesquiterpenes & 9.43 & \\
monoterpenesphenolics & & 0.10 & 2.21 \\
Others & & & \\
\hline
\end{tabular}

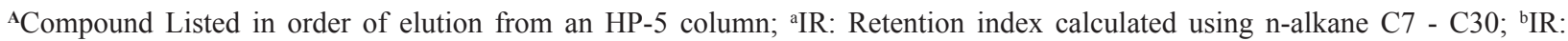
Identification based on retention index reported by Adams (2012) and cidentification based on comparison of mass spectra using Wiley 275 library; Relative area (\%): percentage of the area occupied by the compounds in the chromatogram; n.i: non-identified compounds; IM: Methods of identification.

\section{Results and Discussion}

As shown in Tables 1, 2, and 3, the L. alba EO presented 46 compounds, 40 of which were identified, with the major ones being: geranial, $35.07 \%$; neral, 27.8\%; and trans-caryophyllene, $6.72 \%$ ). The C. citratus EO presented 28 compounds, 24 of which were identified, with the major ones being: geranial $/ \alpha$-citral, $42.88 \%$; $\beta$-citral, $32.15 \%$; and myrcene, $9.82 \%$. The $O$. vulgare EO presented 44 compounds, with the major ones being: carvacrol, 18.97\%; trans-sabinene hydrate, $17.75 \%$; and terpinen-4-ol, $7.57 \%$. These values refer to the relative area (\%) that the compounds occupy within the chromatogram.

Table 2. Chemical composition of Cymbopogon citratus essential oil.

\begin{tabular}{clccc}
\hline Peak & \multicolumn{1}{c}{${ }^{\mathrm{A}}$ Compounds } & ${ }^{\mathrm{a}} \mathrm{RI}_{\text {cal }}$ & Área $\%$ & $\mathrm{IM}$ \\
\hline 1 & 6- metil-5-hepten-2-one & 989 & 0.39 & $\mathrm{a}, \mathrm{b}, \mathrm{c}$ \\
2 & Mircene & 994 & 9.82 & $\mathrm{a}, \mathrm{b}, \mathrm{c}$ \\
3 & Cis- $\beta$-ocimene & 1041 & 0.42 & $\mathrm{a}, \mathrm{b}, \mathrm{c}$ \\
4 & Trans- $\beta$-ocimene & 1052 & 0.23 & $\mathrm{a}, \mathrm{b}, \mathrm{c}$ \\
5 & Citronellal & 1095 & 0.24 & $\mathrm{a}, \mathrm{b}, \mathrm{c}$ \\
6 & $\alpha$-ciclocitral & 1101 & 1.24 & $\mathrm{a}, \mathrm{c}$ \\
7 & Linalool & 1149 & 0.34 & $\mathrm{a}, \mathrm{c}$ \\
8 & Fotocitral A & 1153 & 0.23 & $\mathrm{a}, \mathrm{c}$ \\
9 & Trans- $p$-menta-1(7),8-dien-2-ol & 1157 & 0.17 & $\mathrm{a}, \mathrm{b}, \mathrm{c}$ \\
10 & Mirtenol & 1168 & 1.48 & $\mathrm{a}, \mathrm{b}, \mathrm{c}$ \\
11 & Trans-4- caranone & 1185 & 1.94 & $\mathrm{a}, \mathrm{b}, \mathrm{c}$ \\
12 & n.i & 1196 & 0.17 & $\mathrm{a}, \mathrm{b}$ \\
& & & & continue
\end{tabular}


continuation

\begin{tabular}{|c|c|c|c|c|}
\hline 13 & Nerol & 1239 & 0.58 & $a, b, c$ \\
\hline 14 & $\beta$-citral & 1251 & 32.15 & $\mathrm{a}, \mathrm{c}$ \\
\hline 15 & Geraniol & 1265 & 4.5 & $\mathrm{a}, \mathrm{b}, \mathrm{c}$ \\
\hline 16 & $\alpha$ - citral & 1283 & 42.88 & $\mathrm{a}, \mathrm{c}$ \\
\hline 17 & n.i & 1297 & 0.4 & $a, b$ \\
\hline 18 & Piperitenone & 1342 & 0.33 & $\mathrm{a}, \mathrm{b}, \mathrm{c}$ \\
\hline 19 & Geranic acid & 1367 & 0.36 & $\mathrm{a}, \mathrm{c}$ \\
\hline 20 & n.i & 1378 & 0.47 & $a, b$ \\
\hline 21 & Neril acetate & 1387 & 0.44 & $a, b, c$ \\
\hline 22 & $\beta$-cariophyllene & 1420 & 0.19 & $\mathrm{a}, \mathrm{c}$ \\
\hline 23 & Trans- $\alpha$-bergamotene & 1438 & 0.09 & $a, b, c$ \\
\hline 24 & Trans- $\beta$-farnesene & 1464 & 0.16 & $a, b, c$ \\
\hline 25 & 2-tridecanone & 1495 & 0.32 & $a, b, c$ \\
\hline 26 & Cariophyillene oxide & 1582 & 0.1 & $\mathrm{a}, \mathrm{b}, \mathrm{c}$ \\
\hline 27 & 1-epi-cubenol & 1621 & 0.18 & $\mathrm{a}, \mathrm{b}, \mathrm{c}$ \\
\hline 28 & n.i & 1706 & 0.19 & $\mathrm{a}, \mathrm{c}$ \\
\hline & Total identified compounds & & 96.00 & \\
\hline & monoterpenes hydrocarbons & & 10.47 & \\
\hline & oxygenated monoterpenes & & 86.64 & \\
\hline & sesquiterpene hydrocarbons & & 0.44 & \\
\hline & oxygenated sesquiterpenes & & 0.28 & \\
\hline & monoterpenesphenolics & & 0.00 & \\
\hline & Others & & 2.17 & \\
\hline
\end{tabular}

${ }^{\mathrm{A}}$ Compound Listed in order of elution from an HP-5 column; ${ }^{\mathrm{a} I R}$ : Retention index calculated using n-alkane C7 - C30; ${ }^{\text {IR: }}$ Identification based on retention index reported by Adams (2012) and cidentification based on comparison of mass spectra using Wiley 275library; Relative area (\%): percentage of the area occupied by the compounds in the chromatogram; n.i: non-identified compounds; IM: Methods of identification.

Table 3. Chemical composition of Origanum vulgare essential oil.

\begin{tabular}{clccc}
\hline Peak & \multicolumn{1}{c}{${ }^{\mathrm{A}}$ Compounds } & ${ }^{\mathrm{a}} \mathrm{RI}_{\text {cal }}$ & Área $\%$ & $\mathrm{IM}$ \\
\hline 1 & Trans-2-hexenal & 860 & 0.11 & $\mathrm{a}, \mathrm{b}, \mathrm{c}$ \\
2 & $\alpha$-thujene & 944 & 0.85 & $\mathrm{a}, \mathrm{b}, \mathrm{c}$ \\
3 & $\alpha$-pinene & 951 & 0.51 & $\mathrm{a}, \mathrm{b}, \mathrm{c}$ \\
4 & Sabinene & 992 & 3.22 & $\mathrm{a}, \mathrm{b}, \mathrm{c}$ \\
5 & Mircene & 1010 & 1.49 & $\mathrm{a}, \mathrm{b}, \mathrm{c}$ \\
6 & $\alpha$-phellandrene & 1022 & 0.12 & $\mathrm{a}, \mathrm{b}, \mathrm{c}$ \\
7 & $\alpha$-terpinene & 1035 & 2.71 & $\mathrm{a}, \mathrm{b}, \mathrm{c}$ \\
8 & $\rho$-cimene & 1044 & 6.68 & $\mathrm{a}, \mathrm{b}, \mathrm{c}$ \\
9 & $\beta$-phellandrene & 1047 & 1.65 & $\mathrm{a}, \mathrm{b}, \mathrm{c}$ \\
10 & cis- $\beta$-ocimene & 1057 & 2.63 & $\mathrm{a}, \mathrm{b}, \mathrm{c}$ \\
11 & Trans- $\beta$-ocimene & 1066 & 0.41 & $\mathrm{a}, \mathrm{b}, \mathrm{c}$ \\
& & & & continue
\end{tabular}


continuation

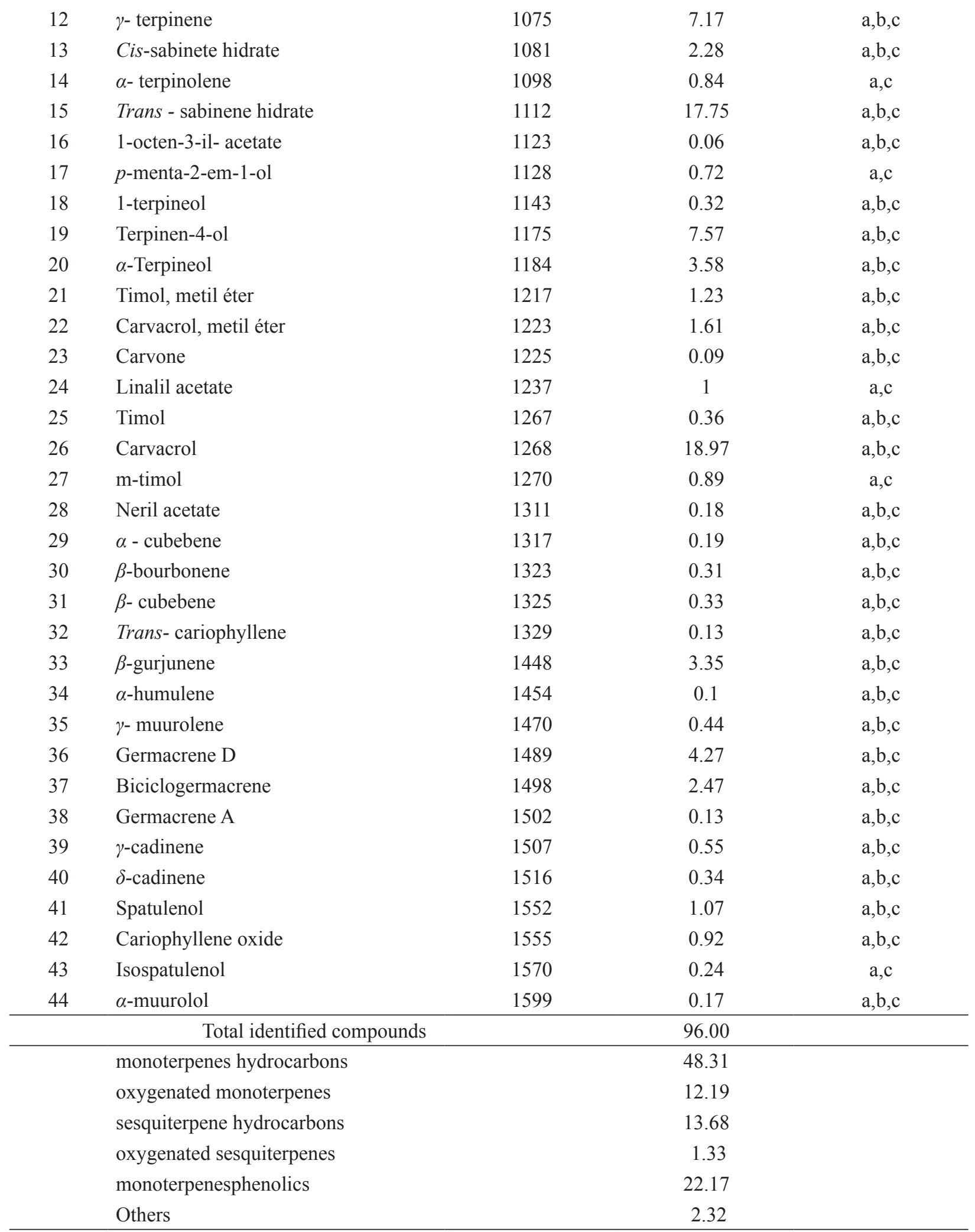

${ }^{\mathrm{A}}$ Compound Listed in order of elution from an HP-5 column; aR: Retention index calculated using n-alkane C7 - C30; ${ }^{\text {IIR: }}$ Identification based on retention index reported by Adams (2012) and cidentification based on comparison of mass spectra using Wiley 275library; Relative area (\%): percentage of the area occupied by the compounds in the chromatogram; n.i: non-identified compounds; IM: Methods of identification. 
Escobar et al. (2010) assessed EOs obtained from the aerial part of nine species of $L$ alba from different locations in Colombia and showed that geranial and neral were also among the major compounds; however, both geranial and neral were identified in only three species, ranging from 23.3 to $28.9 \%$ for geranial, and 19.5 to $21.5 \%$ for neral, showing that the different species of $L$. alba had different components depending on the planting site.

An assessment of the composition of L. alba EO from fresh leaves harvested in the four seasons (spring, summer, fall, and winter) in a Medicinal Garden located in the state of Paraná, Nogueira et al. (2007) showed that the components varied during the seasons, so that the major compound was trans-dihydrocarbon in spring and summer, and geranial was the major compound in fall and winter. This suggests that, when analyzing an EO, results can differ based on several factors such as climate and location.

By analyzing the chemical composition of $C$. citratus EO using two forms of drying (oven-drying at $40^{\circ} \mathrm{C}$, and room temperature using a moisture dryer) and a three dry matter fragmentation process (powder obtained in mill, $1 \mathrm{~cm}$ and $20 \mathrm{~cm}$ fragments), Costa et al. (2005) observed that geranial was the major compound, regardless of fragmentation and drying, corroborating our results.

Unlike our findings, Araújo et al. (2015) identified 25 compounds in the oregano OE, with the two major ones being 4-terpineol and thymol, and with carvacrol not being detected as major compound. However, in the present study, samples of fresh oregano leaves were collected, while Araújo et al. (2015) used dry leaves from the local market of São Luís, Maranhão. By assessing five commercial brands of oregano EO, Silva et al. (2010) showed that the major component in all oils was carvacrol, corroborating our results.

PCA of the major classes of the three analyzed oils was performed (Figure 1). The presence of oxygenated monoterpenes as the major class in $L$. alba $(71.11 \%)$ and C. citratus $(86.64 \%)$ EOs was observed, whereas monoterpene hydrocarbons were the major class $(48.31 \%)$ in O. vulgare EO.

S. rubidaea has already been isolated from dogs with otitis externa (YAMAMOTO et al., 2010). In addition, it has been isolated from patients with urinary tract infection (MENEZES et al., 2004) and from the water from bathroom taps of a higher education institution (OLIVEIRA FILHA et al., 2018), depicting its detrimental effect on public health.

Jha et al. (2016) reported that $K$. aerogenes was an important pathogen in acquired hospital infections. In a study assessing the urine of dogs and cats with clinical suspicion of urinary infection, Carvalho et al. (2014) isolated $K$. aerogenes, showing its importance, as the animal can be infected by consuming food sold in bulk. 
Figure 1. Biplot with representation of the chemical class projection of the Lippia alba, Cymbopogon citratus and Origanum vulgare essential oils.

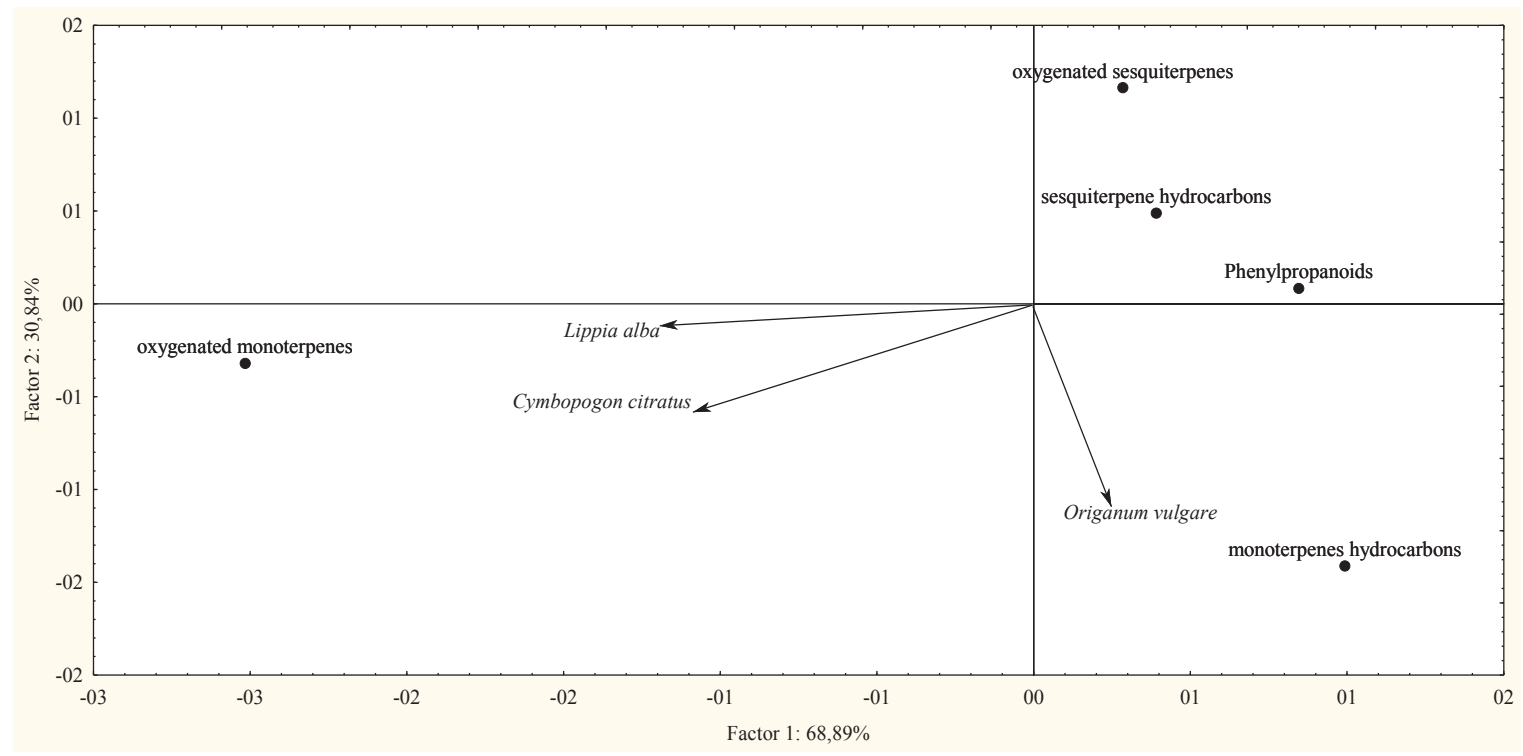

As for the cat food samples, 16 gram-negative microorganisms, with predominance of $S$. rubidaea $(\mathrm{n}=5)$ and $K$. aerogenes $(\mathrm{n}=6)$, and seven gram-positive microorganisms, predominantly Corynebacterium kutscheri $(\mathrm{n}=3)$, were isolated (Figure 2).

Figure 2. Number of bacterial isolates (Gram-negative and Gram-positive) from samples of cat food sold in bulk.

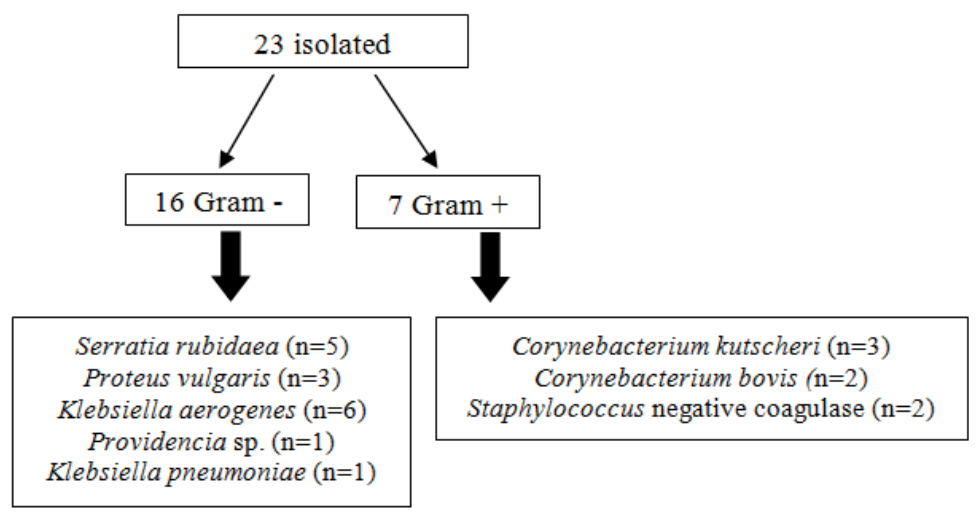

The MIC for each of the isolated microorganisms did not show significant differences for the different EOs tested (L. alba, C. citratus, and O. vulgare) (Table 4). The lowest MIC mean value was obtained for the C. citratus EO $(0.83 \mathrm{mg} / \mathrm{mL})$ for two isolated gram-positive bacteria (coagulase-negative Staphylococcus and C. kutscheri).
In serovar samples of the gram-negative bacterium Salmonella enterica of poultry origin, Santurio et al. (2007) found a mean MIC of 0.53 $\mathrm{mg} / \mathrm{mL}$ for $O$. vulgare $\mathrm{EO}$, a lower value than that observed in the present study considering the gramnegative bacteria isolated. 
Aquino et al. (2010) observed that the MIC for L. alba EO was $0.0016 \mathrm{mg} / \mathrm{mL}$ and $0.0062 \mathrm{mg} / \mathrm{mL}$ for strains of Salmonella spp. compared to most strains of $S$. aureus isolated from beef samples sold at the local markets in the city of Aracajú, Sergipe. However, their MIC values were relatively lower in comparison to the estimates of the present study.

Table 4. Mean \pm standard error of the minimum inhibitory concentration $(\mathrm{mg} / \mathrm{mL})$ of the essential oils made of oregano (O. vulgare), lemon grass (C. citratus) and Brazilian lemon balm (L. alba) in comparison to bacterial isolates from cat food sold in bulk.

\begin{tabular}{lccc}
\hline \multirow{2}{*}{\multicolumn{1}{c}{ Isolated microorganism }} & \multicolumn{3}{c}{ Essential oil } \\
\cline { 2 - 4 } & $\begin{array}{c}\text { Oregano } \\
\text { O. vulgare }\end{array}$ & $\begin{array}{c}\text { Lemon grass } \\
\text { C._citratus }\end{array}$ & $\begin{array}{c}\text { Brazilian lemon balm } \\
\text { L. alba }\end{array}$ \\
\hline Serratia rubidaea $(\mathrm{n}=5)^{*}$ & $1.37 \pm 0.19$ & $0.87 \pm 0.08$ & $1.12 \pm 0.16$ \\
Proteus vulgaris $(\mathrm{n}=3)^{*}$ & $1.25 \pm 0.25$ & $1.04 \pm 0.10$ & $1.04 \pm 0.10$ \\
Klebsiella aerogenes $(\mathrm{n}=6)^{*}$ & $1.18 \pm 0.13$ & $1.00 \pm 0.07$ & $1.04 \pm 0.07$ \\
Providencia species $(\mathrm{n}=1)^{*}$ & $1.46 \pm 0.55$ & $1.04 \pm 0.21$ & $1.04 \pm 0.21$ \\
Klebsiella pneumoniae $(\mathrm{n}=1)^{*}$ & $1.04 \pm 0.21$ & $1.04 \pm 0.21$ & $1.04 \pm 0.21$ \\
Staphylococcus negative coagulase $(\mathrm{n}=2)^{* *}$ & $1.46 \pm 0.35$ & $0.83 \pm 0.13$ & $1.04 \pm 0.13$ \\
Corynebacterium kutscheri $(\mathrm{n}=3)^{* *}$ & $1.18 \pm 0.19$ & $0.83 \pm 0.10$ & $1.18 \pm 0.19$ \\
Corynebacterium bovis $(\mathrm{n}=2)^{* *}$ & $1.25 \pm 0.28$ & $1.25 \pm 0.28$ & $1.04 \pm 0.13$ \\
\hline
\end{tabular}

For all isolates, the analyzes were done in triplicate.

Values in the same line did not differ by the Kruskal-wallis test $(\mathrm{P}>0.05)$

* gram-negative bacteria;** gram-positive bacteria.

As for the resistance to the main antimicrobials used in the feline clinic, the results were analyzed as mean of inhibition halos for the 10 antimicrobials tested in association or not with one of the EOs for the main microorganisms isolated ( $K$. aerogenes, P. vulgaris, and $S$. rubidaea) (Table 5). For $S$. rubidaea, significant difference in inhibition halo diameter was observed for the association of antibiotic amoxicillin (AMO) with the oregano EO compared to the association with lemon grass EO (Table 5), and there were no differences in relation to the analysis of the isolated antibiotic. However, for the other microorganisms ( $K$. aerogenes and $P$. vulgaris), there were no differences in inhibition halo diameter when the EOs tested were included (Table 5). 
Table 5. Mean of the inhibition halo diameter $(\mathrm{mm})$ for 10 tested antibiotics, in combination with or without essential oils (Origanum vulgare (OV), Cymbopogon citratus (CC), or Lippia alba (LA)), on the main microorganisms isolated (Klebsiella aerogenes $(\mathrm{n}=6)$, Serratia rubidaea $(\mathrm{n}=5)$, and Proteus vulgaris $(\mathrm{n}=3)$ ) from samples of cat food sold in bulk.

\begin{tabular}{|c|c|c|c|c|c|c|c|c|c|c|}
\hline & CIP & GEN & $\mathrm{AMO}$ & PEN & CFL & CTF & AMC & TET & TOB & AMP \\
\hline & \multicolumn{10}{|c|}{ Klebsiella aerogenes } \\
\hline ATB & 30,0 & 18,5 & 7,3 & 0,0 & 8,2 & 19,3 & 14,2 & 10,3 & 17,5 & 5,7 \\
\hline $\mathrm{ATB}+\mathrm{OV}$ & 29,5 & 17,7 & $\uparrow 10,2$ & 0,0 & 5,8 & $\uparrow 22,8$ & 13,5 & $\uparrow 14,2$ & $\uparrow 17,7$ & $\uparrow 10,0$ \\
\hline $\mathrm{ATB}+\mathrm{CC}$ & 28,7 & $\uparrow 21,8$ & $\uparrow 9,0$ & 0,0 & 6,2 & $\uparrow 24,0$ & $\uparrow 17,2$ & $\uparrow 11,0$ & $\uparrow 19,7$ & $\uparrow 9,5$ \\
\hline \multirow[t]{2}{*}{$\mathrm{ATB}+\mathrm{LA}$} & 29,5 & $\uparrow 19,3$ & $\uparrow 8,5$ & 0,0 & 5,7 & 18,5 & $\uparrow 15,5$ & $\uparrow 12,8$ & 17,2 & $\uparrow 8,3$ \\
\hline & \multicolumn{10}{|c|}{ Serratia rubidaea } \\
\hline ATB & 27,8 & 21,6 & $12^{\mathrm{ab}}$ & 3,8 & 12,8 & 21,8 & 16,8 & 17,2 & 21,4 & $14,4^{\mathrm{a}}$ \\
\hline $\mathrm{ATB}+\mathrm{OV}$ & 24,8 & $\uparrow 22,2$ & $12,4^{\mathrm{a}}$ & $\uparrow 5,8$ & $\uparrow 15,0$ & 21,0 & $\uparrow 22,0$ & $\uparrow 17,8$ & 21,0 & $12,6^{\mathrm{ab}}$ \\
\hline $\mathrm{ATB}+\mathrm{CC}$ & 26,4 & $\uparrow 21,8$ & $11,0^{\mathrm{b}}$ & $\uparrow 6,6$ & $\uparrow 13,2$ & 20,0 & $\uparrow 23,0$ & $\uparrow 18,0$ & $\uparrow 21,6$ & $11,4^{\mathrm{b}}$ \\
\hline \multirow[t]{2}{*}{$\mathrm{ATB}+\mathrm{LA}$} & 25,4 & 21,6 & $11,4^{\mathrm{ab}}$ & $\uparrow 5,4$ & $\uparrow 13,8$ & 18,6 & $\uparrow 22,4$ & 15,8 & 20,2 & $12,6^{\mathrm{ab}}$ \\
\hline & \multicolumn{10}{|c|}{ Proteus vulgaris } \\
\hline ATB & 26,0 & 22,3 & 10,3 & 0,0 & 0,0 & 14,7 & 19,7 & 20,3 & 18,7 & 8,0 \\
\hline $\mathrm{ATB}+\mathrm{OV}$ & 26,0 & $\uparrow 24,0$ & $\uparrow 12,3$ & $\uparrow 5,3$ & $\uparrow 2,3$ & 11,7 & $\uparrow 20,0$ & 20,0 & $\uparrow 20,0$ & $\uparrow 10,7$ \\
\hline $\mathrm{ATB}+\mathrm{CC}$ & 24,7 & 20,0 & 8,7 & 0,0 & 0,0 & 9,3 & 18,0 & 17,0 & 16,0 & 7,0 \\
\hline $\mathrm{ATB}+\mathrm{LA}$ & $\uparrow 26,3$ & $\uparrow 23,0$ & 8,0 & $\uparrow 2,3$ & 2,0 & 11,3 & 19,3 & $\uparrow 20,7$ & $\uparrow 20,0$ & $\uparrow 9,7$ \\
\hline
\end{tabular}

ATB: Antibiotic; CIP: Ciprofloxacin; GEN: Gentamicin; AMO: Amoxicillin; PEN: Penicillin; CFL: Cephalotin; CTF: Ceftiofur; AMC: Amoxicillin + clavulanate; TET: Tetracycline; TOB: Tobramycin; AMP: Ampicillin; above the mean halo diameter of antibiotic inhibition. Means followed by different letters in the column differ by the Tukey test $(\mathrm{p}<0.05)$; Not significant by ANOVA or Kruskal-wallis.

Although no differences were found in inhibition halo diameters when there was an association with the EOs tested, an increasing trend was observed for inhibition halo diameters when there was an association with the EOs tested for the vast majority of the antibiotics tested (Table 5).

According to Alves et al. (2011), the interference of the EOs with the action of the antibiotic varies by antibiotic (amoxicillin, azithromycin, erythromycin), EO tested (Eucalyptus globules L., Eugenia uniflora L., and Mentha piperita), and type of bacterial strain analyzed, showing differences in inhibition (antagonism and synergism) results and a need for new studies assessing the use of EOs in association with antibiotics routinely used in feline clinics. Moreover, Mugnaini et al. (2012) suggested that the EOs should be carefully administered in animals, especially in cats considering their potential toxicity.

\section{Conclusion}

L. alba, C. citratus, and O. vulgare EOs are effective in inhibiting the growth of gram-positive and gram-negative bacteria, with MICs varying between 0.83 and $1.46 \mathrm{mg} / \mathrm{mL}$; the lowest MIC was obtained for $C$. citratus EO. However, new studies are needed to evaluate their use in the diet of domestic felines.

\section{Acknowledgements}

The authors would like to thank UNIPAR for funding this research. This study was financed in part by the Coordination for the Improvement of Higher Education Personnel [Coordenação de Aperfeiçoamento de Pessoal de Nivel Superior], Brazil (CAPES), Finance Code 001. 


\section{References}

ADAMS, R. P. Identification of essential oil components by gas chromatography/mass spectroscopy. Carol Stream: Allured Publshing Corporation, 2012. 469 p.

ALVES, L. A.; FREIRES, I. A.; JOVITO, V. C.; ALMEIDA, L. F. D.; CASTRO, R. D. Interferência de óleos essenciais sobre antibióticos utilizados no tratamento de infecções da cavidade oral. International Journal of Dentistry, Recife, v. 10, n. 1, p. 26-31, jan./ mar. 2011.

AQUINO, L. C. L.; SANTOS, G. G.; TRINDADE, R. C.; ALVES, J.A. B.; SANTOS, P. O.; ALVES, P. B.; BLANK, A. F.; CARVALHO, L. M. Atividade antimicrobiana dos óleos essenciais de erva-cidreira e manjericão frente a bactérias de carnes bovinas. Alimentos e Nutrição, Araraquara, v. 21, n. 4, p. 529-535, out./dez. 2010.

ARAÚJO, L. S.; ARAÚJO, R. S.; SERRA, J. L.; NASCIMENTO, A. R. Composição química e susceptibilidade do óleo essencial de orégano (Origanum vulgare L., família Lamiaceae) frente à cepas de Escherichia coli, Staphylococcus aureus e Salmonella choleraesuis. Boletim do Centro de Pesquisa de Processamento de Alimentos, Curitiba, v. 33, n. 1, p. 7378, jan./jun. 2015. DOI: 10.5380/cep.v33i1.43808

ARAÚJO, M. M.; LONGO, P. L. Teste da ação antibacteriana in vitro de óleo essencial comercial de Origanum vulgare (orégano) diante das cepas de Escherichia coli and Staphylococcus aureus. Arquivos do Instituto Biológico, São Paulo, v. 83, p. 1-7, 2016. DOI: 10.1590/1808-1657000702014.

ASSIS, Y. P. A. S.; ALMEIDA, A. C.; NOGUEIRA, W. C. L.; SOUZA, C. N.; GONÇALVES, S. F.; SILVA, F. E. G.; SANTOS, V. K. F. R.; MARTINS, E. R. Atividade antimicrobiana e estabilidade do óleo essencial de capimlimão (Cymbopogon citratus) microencapsulados em ração para frangos de corte. Revista Brasileira de Saúde e Produção Animal, Salvador, v. 18, n. 4, p. 587-593, 2017. DOI: $10.1590 / \mathrm{s} 1519-99402017000400009$

ASSOCIAÇÃO BRASILEIRA DA INDÚSTRIA DE PRODUTOS PARA ANIMAIS DE ESTIMAÇÃO. FATURAMENTO - ABINPET. 2016 do setor pet aumenta 4,9\% e fecha em R 18,9 bilhões, revela Abinpet. São Paulo: Abinpet, 2017. Disponível em: http://abinpet.org. $\mathrm{br} / \mathrm{site} /$ faturamento-2016-do-setor-pet-aumenta-49-efecha-em-r-189-bilhoes-revela-abinpet/. Acesso em: 10 out. 2017.

ASSOCIAÇÃO BRASILEIRA DA INDÚSTRIA DE PRODUTOS PARA ANIMAIS DE ESTIMAÇÃO. FATURAMENTO - ABINPET. Faturamento do setor crescerá $7,4 \%$ e fechará em r\$ 17,9 bilhões em 2015 . São
Paulo: Abinpet, 2015. Disponível em: http://abinpet.org. $\mathrm{br} /$ site/faturamento-do-setor-crescera-74-e-fechara-emr-179-bilhoes-em-2015/. Acesso em: 10 out. 2017.

AYRES, M.; AYRES JÚNIOR, M.; AYRES, D. L.; SANTOS, A. S. BioEstat: aplicações estatísticas nas áreas das ciências biomédicas. Belém: Universidade Federal do Pará, 2007. 364 p.

BAPTISTA, A. B. As bactérias multiresistentes hospitalares e as plantas medicinais. Revista Desafios, Palmas, v. 4, n. 4, p. 1-2, out./dez. 2017. Disponível em: https://sistemas.uft.edu.br/periodicos/index.php/ desafios/article/view/5030/12706. Acesso em: 12 maio 2018.

CARVALHO, V. M.; SPINOLA, T.; TAVOLARI, F.; IRINO, K.; OLIVEIRA, R. M.; RAMOS, M. C. C. Infecções do trato urinário (ITU) de cães e gatos: etiologia e resistência aos antimicrobianos. Pesquisa Veterinária Brasileira, Seropédica, v. 34, n. 1, p. 62-70, jan. 2014. DOI: 10.1590/S0100-736X2014000100011

\section{CLINICAL AND LABORATORY STANDARDS} INSTITUTE - CLSI. Performance standars for antimicrobial susceptibility testing. CLSI document M100-S15. Wayne: Editora, 2013.

COSTA, L. C. B.; CORRÊA, R. M.; CARDOSO, J. C. W.; PINTO, J. E. B. P.; BERTOLUCCI, S. K. V.; FERRI, P. H. Secagem e fragmentação da matéria seca no rendimento e composição do óleo essencial de capim-limão. Horticultura Brasileira, Brasília, v. 23, n. 4, p. 956-959, out./dez. 2005. DOI: 10.1590/S010205362005000400019

ESCOBAR, P.; LEAL, S. M.; HERRERA, L. V.; MARTINEZ, J. R.; STASHENKO, E. Chemical composition and antiprotozoal activities of Colombian Lippia spp. essential oils and their major components. Memórias do Instituto Osvaldo Cruz, Rio de Janeiro, v. 105 , n. 2 , p. 184-190, 2010. DOI: 10.1590/S007402762010000200013

GAZIM, Z. C.; AMORIM, A. C.; HOVELL, A. M.; REZENDE, C. M.; NASCIMENTO, I. A.; FERREIRA, G. A.; CORTEZ, D. A. Seasonal variation, chemical composition, and analgesic and antimicrobial activities of the essential oil from leaves of Tetradenia riparia (Hochst.) Coddin southern Brazil. Molecules, Basel, v. 15 , n. 10 , p. 5509-5524, ago. 2010. DOI: 10.3390/ molecules 15085509

GAZIM, Z. C.; DEMARCHI, I. G.; LONARDONI, M. V.; AMORIM, A. C.; HOVELL, A. M.; REZENDE, C. M.; FERREIRA, G. A.; LIMA, E. L.; COSMO, F. A.; CORTEZ, D. A. Acaricidal activity of the essential oil from Tetradenia riparia (Lamiaceae) on the cattle tick 
Rhipicephalus (Boophilus) microplus (Acari; Ixodidae). Experimental Parasitology, Orlando, v. 129, n. 12, p. 175-178, 2011. DOI: 10.1016/j.exppara.2011.06.01

GOMES, G. A.; MONTEIRO, C. M. O.; SENRA, T. O. S.; ZERINGOTA, V.; CALMON, F.; MATOS, R. S.; DAEMON, E.; GOIS, R. W. S.; SANTIAGO, G. M. P.; CARVALHO, M. G. Chemical composition and acaricidal activity of essential oil from Lippia sidoides on larvae of Dermacentor nitens (Acari: Ixodidae) and larvae and engorged females of Rhipicephalus microplus (Acari: Ixodidae). Parasitology Research, v. 111, n. 6, p. 1-8, 2012. DOI: 10.1007/s00436-012-3101-9

HAIR, J. F.; ANDERSON, R. E.; TATHAM, R. L.; BLACK, W.; HAIR, J. Análise multivariada de dados. Tradução Adonai Schlup Sant'Anna e Anselmo Chaves Neto. 5. ed. Porto Alegre: Bookman, 2005. 593 p.

INTERNATIONAL ORGANIZATION FOR STANDARDIZATION. ISO 6887-4 - Microbiology of food and animal feeding stuffs - preparation of test samples, initial suspension and decimal dilutions for microbiological examination. Switzerland: ISO, 2003.

JHA, P.; KIM, C.; KIM, D.; CHUNG, J.; YOON, N.; JHA, B.; KIM, S. W.; JANG, S. J.; AHN, Y.; CHUNG, J. K.; JEON, D. Y. Transmission of Enterobacter aerogenes septicemia in healthcare workers. Springer Plus, Switzerland, v. 5, n. 1397, p. 1-4, 2016. DOI: 10.1186/ s40064-016-3011-x

KOKETSU, M.; GONÇALVES, S. L. Óleos essenciais e sua extração por arraste a vapor. Rio de Janeiro: EMBRAPA-CTAA, 1991. 24 p.

MENEZES, E. A.; CEZAFAR, F. C.; ANDRADE, M. S. S.; ROCHA, M. V. A. P.; CUNHA, F. A. Frequência de Serratia sp em infecções urinárias de pacientes internados na Santa Casa de Misericórdia em Fortaleza. Revista da Sociedade Brasileira de Medicina Tropical, Uberaba, v. 37, n. 1, p. 70-71, fev. 2004. DOI: 10.1590/ S0037-86822004000100020

MOITA NETO, J. M.; MOITA, G. C. An introduction analysis exploratory multivariate date. Química Nova, São Paulo, v. 21, n. 4, p. 467-469, 1998. DOI: 10.1590/ S0100-40421998000400016

MUGNAINI, L.; NARDONI, S.; PINTO, L.; PISTELLI, L.; LEONARDI, M.; PISSERI, F.; MANCIANTI, F. In vitro and in vivo antifungal activity of some essential oils against feline isolates of Microsporum canis. Journal de Mycologie Médicale, Paris, v. 22, p. 179-184, jun. 2012.

NASCIMENTO, J. M. L.; CAVALCANTE, M. B.; AMARANTE, J. F.; KREWER, C. C.; COSTA, M. M. Ação antimicrobiana de óleo essencial frente a cepas bacterianas contaminantes de alimentos. Acta Veterinaria
Brasilica, Mossoró, v. 8, n. 3, p. 221-225, out./dez. 2014. DOI: 10.21708/avb.2014.8.3.4314

NOGUEIRA, M. A.; DIAZ, G.; SAKUMO, L. Caracterização química e atividade biológica do óleo essencial de Lippia alba cultivada no Paraná. Revista de Ciências Farmacêuticas Básica e Aplicada, Araraquara, v. 28, n. 3, p. 273-278, set./dez. 2007.

OLIVEIRA, M. M. M.; BRUGNERA, D. F.; CARDOSO, M. G.; GUIMARÃES, L. G. L.; PICCOLI, R. H. Rendimento, composição química e atividade antilisterial de óleos essenciais de espécies de Cymbopogon. Revista Brasileira de Plantas Medicinais, v. 13, n. 1, p. 8-16, 2011. DOI: $10.1590 / \mathrm{S} 1516-05722011000100002$

OLIVEIRA FILHA, H. M. C.; ROCHA, J. R. G.; MATOS-ROCHA, T. J.; PIMENTEL, E. C.; GRIZ, S. A. S.; LOPES, V. C. M.; RODRIGUES, M. M. L. Ocorrência de agentes infecciosos em torneiras dos banheiros de uma instituição de ensino superior. Arquivos Médicos dos Hospitais e da Faculdade de Ciências Médicas da Santa Casa de São Paulo, São Paulo, v. 63, n. 1, p. 25-30, jan./ abr. 2018. DOI: 10.26432/1809-3019.2018.63.1.25

OMOLO, M. O.; OKINYO, D.; NDIEGE, I. O.; LWANDE, W.; HASSANALI, A. Repellency of essential oils of some Kenyan plants against Anopheles gambiae. Phytochemistry, London, v. 65, n. 20, p. 2797-2802, out. 2004. DOI: $10.1016 /$ j.phytochem.2004.08.035

QUINN, P. J. Clinical veterinary microbiology. St. Louis: Mosby, 1994. 627 p.

ROCHA, H. C. R.; ALVARENGA, C. D.; GIUSTOLIN, T. A.; BRANT, R. S.; SOUZA, M. D. C.; SARMENTO, H. G. S.; BARBOSA, M. G. Crescimento, produção de fitomassa e teor de óleo essencial de folhas de capim citronela (Cymbopogon nardus (L.) Rendle) em cultivo consorciado com algodoeiro colorido no semiárido mineiro. Revista Brasileira de Plantas Medicinais, Botucatu, v. 14, p. 183-187, jul. 2012. DOI: 10.1590/ S1516-05722012000500010

SANTOS, J. C.; CARVALHO FILHO, C. D.; BARROS, T. F.; GUIMARÃES, A. G. Atividade antimicrobiana in vitro dos óleos essenciais de orégano, alho, cravo e limão sobre bactérias patogênicas isoladas de vôngole. Semina: Ciências Agrárias, Londrina, v. 32, n. 4, p. 1557-1564, out./dez. 2011. DOI:

SANTURIO, J. M.; SANTURIO, D. F.; POZZATTI, P.; MORAES, C.; FRANCHIN, P. R.; ALVES, S. H. Atividade antimicrobiana dos óleos essenciais de orégano, tomilho e canela frente a sorovares de Salmonella enterica de origem avícola. Ciência Rural, Santa Maria, v. 37, n. 3, p. $803-808$, 2007. DOI: $10.5433 / 1679-0359.2011 v 32$ $\mathrm{n} 4 \mathrm{p} 1557$ 
SARTORATTO, A.; MACHADO, A. L. M.; DELARMELINA, C.; FIGUEIRA, G. M.; DUARTE, M. C.T.; REHDER, V. L. G. Composition and antimicrobial activity of essential oils from aromatic plants used in Brazil. Brazilian Journal of Microbiology, Rio de Janeiro, v. 35, n. 4, p. 275-280, Dec. 2004. doi: 10.1590/ S1517-83822004000300001

SILVA, J. P. L.; DUARTE-ALMEIDA, J. M.; PEREZ, D. V.; FRANCO, B. D. G. M. Óleo essencial de orégano: interferência da composição química na atividade frente a Salmonella Enteritidis. Revista de Ciência e Tecnologia de Alimentos, Campinas, v. 30, p. 136141, maio 2010. Suplemento 1.DOI: 10.1590/S010120612010000500021

SIMÕES, C. M.; SPITZER, V. Óleos voláteis. In: SIMÕES, C. M.; SPITZER, V. Farmacognosia da planta ao medicamento. 3. ed. Porto Alegre: Editora da Universidade Federal do Rio Grande do Sul, 2002. p. $397-425$.
STATSOFT Inc. Statistica for Windows (Computer Program Manual). California: Tibco, 2018. Available at: http://www.statsoft.com/. Accessed at: july 172001.

SUBRAMANIAN, P.; TAKWA, C. W. I. C. W.; ZUBAIR, N. E. A. Chemical composition and antibacterial activity of essential oil of Cymbopogon citratus and Cymbopogon nardus against Enterococcus faecalis. International Journal of Biosciences, Dhaka, v. 6, n. 9, p. 9-17, May. 2015. DOI: $10.1590 / \mathrm{S} 1517-83822004000300001$

YAMAMOTO, D. M.; COLINO, V. C. M.; LEAL, C. R. B.; BABO-TERRA, V. J. Otite externa canina em Campo Grande, Mato Grosso do Sul. PUBVET, Londrina, v. 4, n. 27, Ed. 132, Art. 898, 2010. 